Document downloaded from:

http://hdl.handle.net/10251/63090

This paper must be cited as:

Pellicer Armiñana, E.; Sierra Varela, LA.; Yepes Piqueras, V. (2016). Appraisal of infrastructure sustainability by graduate students using an active-learning method. Journal of Cleaner Production. 113:884-896. doi:10.1016/j.jclepro.2015.11.010.

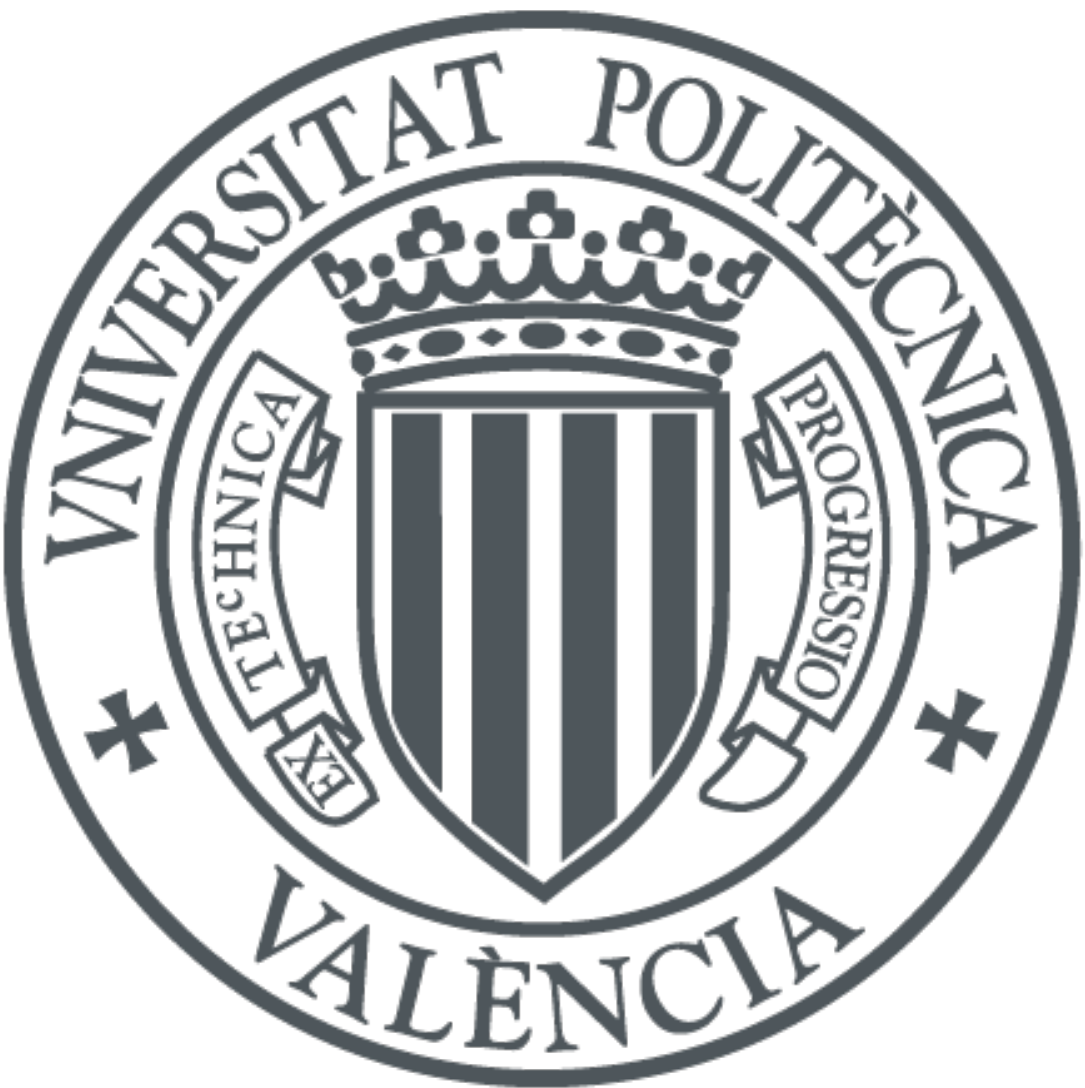

The final publication is available at

http://dx.doi.org/doi:10.1016/j.jclepro.2015.11.010

Copyright Elsevier

Additional Information 


\title{
Appraisal of infrastructure sustainability by graduate students using an active-learning method
}

\author{
Eugenio Pellicer \\ Corresponding Author: \\ Associate Professor, School of Civil Engineering, Universitat Politècnica de València, \\ Camino de Vera s/n, 46022 Valencia, Spain, +34.963.879.562 (phone), +34.963.877.569 \\ (fax), pellicer@upv.es. \\ Leonardo A. Sierra \\ Instructor, Dept. of Civil Construction Works, Universidad de La Frontera, Francisco Salazar \\ 01145, Temuco, Chile, leonardo.sierra@ufrontera.cl.

\section{Víctor Yepes} \\ Associate Professor, ICITECH, Universitat Politècnica de València, Camino de Vera s/n, \\ 46022 Valencia, Spain, vyepesp@upv.es.
}




\title{
Appraisal of infrastructure sustainability by graduate students using an active-learning method
}

\begin{abstract}
Currently many university programs in the construction field do not take sustainability into account from a holistic viewpoint. This may cause a lack of sensitivity from future professionals concerning sustainability. Academics in construction must endeavor to instill a culture of sustainability in the curricula of their students. Therefore, this study proposes an active-learning method that allows graduate students in the construction field to take into consideration infrastructure sustainability from a variety of perspectives in a participatory process. The students applied an analytical hierarchical process to determine the appraisal degree of each criterion. A cluster statistical analysis was carried out, aiming to identify the profiles that influence decision-making. This method was applied to two classes of graduate students enrolled in the Master of Planning and Management in Civil Engineering at the Universitat Politècnica de València. This method identified a correlation between the profiles toward sustainability and the characteristics of the chosen infrastructure. It was also found that the method fulfills educational purposes: most of the students obtained more than $65 \%$ of the target learning outcomes. This approach promotes awareness and sensitivity to different points of view of the sustainability in a participatory context. It can be replicated in other contexts so as to obtain appraisals regarding various criteria that help enhance decisionmaking.
\end{abstract}

Keywords: Active Learning; Analytic Hierarchy Process; Construction; Graduate; Infrastructures; Sustainability

\section{Introduction}

The approach to sustainability has shifted the perspective of modern societies. Sustainability is associated with all practices that lead society to persist, survive and succeed in terms of environmental resources, economic development and quality of life to promote human development (Pappas et al. 2011). Phenomena such as global warming and social pressures, among others, are significant challenges that this generation must confront. Human activities are primarily responsible for these issues. Current development does not respond to existing needs without jeopardizing future generations' welfare. This is the core of the "sustainable development” paradigm (WCED 1987).

Universities have a key role to play in creating a sustainable future. They educate professionals who are going to shape and manage the future society in the short term (Wright and Wilton 2012). In the last decade, there has been growing interest in integrating sustainability into university curricula (Boks and Diehl 2006; Wemmenhove and de Groot 2001). Its introduction has been undertaken by adding content to existing courses, one-off workshops, or new courses that supplement current programs (Lozano and Young 2013). Nonetheless, sustainability is a recent idea in modern society, which has not adequately permeated all university strata yet (Lozano 2010; Lozano and Young 2013).

Sustainability is composed of three equally important elements: social, economic and environmental (Labuschagne et al. 2005). However, according to Summers et al. (2004), only one-third of the public understands sustainability that way; the other two-thirds take into 
account only two out of the three aspects, always recognizing the centrality of the environmental component (García-Segura et al. 2014; Torres-Machí et al. 2014). In this line of thought, there are studies (Wright and Wilton 2012; Watson et al. 2013) that affirm that sustainability is considered in higher education only when focused on the environment. While European experts in sustainability emphasize the sociological role of sustainability, most students focus on technology as a solution for environmental issues (Segalas et al. 2010). Additionally, Whitmer et al. (2010) emphasize a lack of successful learning models among the issues of sustainable education.

Aiming to overcome this challenge, Sipos et al. (2008) propose a transformative process that educates people in order to change their frames of reference and worldviews. In this regard, critical thinking processes are vital to boosting learning, rebuilding knowledge and producing new behaviors oriented toward sustainability (Sipos et al. 2008). The Higher Education Academy of the United Kingdom (HEA 2006) also emphasizes the importance of social, environmental and economic integration, confrontation with real-life complexity, the promotion of critical judgment, professional and personal self-reflection and sustainability assessment. Specifically, some studies (Lozano 2010; Lozano and Peattie 2009) have examined the level of awareness in a student's decisions and actions that affect the environment and society. Kagawa (2007) claims that in some instances students are unfamiliar with sustainability, even though they consider it something positive. On the other hand, Byrne et al. (2013) indicate that engineering professionals associate certain concepts with sustainability according to the education they received.

Therefore, several studies (Segalas et al. 2010; Summers et al. 2004; Wright and Wilton 2012) have identified students' understanding of sustainability. In comparison, other studies put forward the need for reflective analysis to create, correct or improve ways of thinking about sustainability and acting in accordance with its principles (Byrne et al. 2013; Lozano 2010; Sipos et al. 2008). Some contributors (Sipos et al. 2008; Steinemann 2003; Whitmer et al. 2010) point out the need to provide new active-learning methods that value judgments on the concept of integral sustainability: learning strategies focused on the student, the development of motivational and practical experiences, or participatory techniques, among others. Bucciarelli et al. (2000) propose project-based techniques to make students learn engineering design. Du et al. (2013) remark on the advantages of problem-based learning that consider the proposals for potential solutions from students. El-Adaway et al. (2015) introduce a hybrid method that combines different techniques, the results of which show that student performance and sense of responsibility increase. Unfortunately, learning strategies focused on infrastructure sustainability are scarce; among the few, Sieffert et al. (2014) propose a set of learning workshops through the design and construction of buildings using waste materials.

Regarding the design and construction of infrastructure, multiple criteria have to be considered in decision-making (Jato-Espino et al. 2014; Arroyo et al. 2015; Torres-Machí et al. 2015). In some cases, these include partial assessment of infrastructure sustainability (Kucukvar et al. 2014; Reyes at al. 2014). However, when these decisions affect sustainability, other opinions have to be considered, because different stakeholders can perceive sustainability according to different degrees of importance (Valdés-Vásquez and Klotz 2013).

Therefore, there is still room for improvement regarding active-learning methods that value multiple criteria regarding sustainability, particularly those focused on construction. From this point of departure, this study proposes an active-learning method for graduate students to appraise infrastructure sustainability from every facet, considering the multiple preferences of 
stakeholders and their effect on decision-making. This method is applied to two classes of students enrolled in the Master of Planning and Management in Civil Engineering at the Universitat Politècnica de València (Spain). This paper is organized as follows. First, it presents the proposal. The next section details the selected reference criteria of sustainability. Then, the practical implementation of the prioritization process and the sensitivity analysis are explained. Finally, the formative process is evaluated, the results are discussed and the conclusions are highlighted.

\section{Methods}

The proposed method is based on active-learning. This approach provides for supporting knowledge conceptualization, development in uncertain contexts and collaborative work by the students (Bucciarelli et al. 2000; Prince 2004; Sieffert et al. 2014). Furthermore, activelearning presents interesting features such as practical implementation in real-life scenarios, critical thinking and participatory action research, which are key elements in learning about sustainability (Du et al. 2013). These reasons motivate the use of an active-learning method in this research. This method was designed according to the layout shown in Fig. 1 which establishes the stages for project prioritization. This method is linked to the education process applied to two classes of graduate students in the construction field. The educational purpose of this method seeks to achieve learning outputs in terms of four aspects: (1) the appropriate interpretation of the integral sustainability criteria and the identification of indicators for case studies; (2) the application of a method that enables the evaluation of sustainability; (3) the identification of project characteristics that affect sustainability; and (4) the understanding of how preferences regarding sustainability (awareness, value judgment of interest and knowledge) influence the final decision-making process.

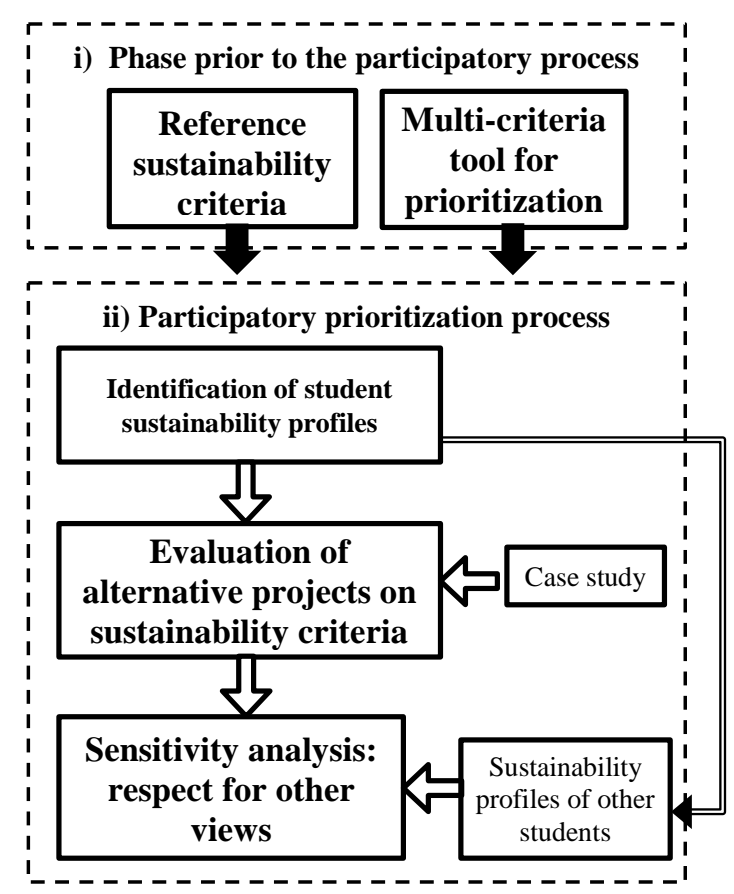

Fig.1. Development outline of the method

This method is based on the issue of prioritization of infrastructure projects regarding their contribution to sustainability; this prioritization is going to be assessed by students. Prior to the participatory process, criteria selection and the evaluation method must be referenced. The criteria are sustainability operating principles that can be identified as a result of the scientific, 
technical and legislative documentation review. They can also be identified by the experts and stakeholders involved during the infrastructure life-cycle (Kumar and Katoch 2014). These criteria facilitate the correct understanding of the sustainability concept.

The prioritization of the project alternatives for the chosen criteria is developed using a multicriteria decision-making tool (Jato-Espino et al. 2014), the purpose of which is to provide a rational and organized structure for the decision-making process. Prioritization starts with the identification of students' profiles regarding sustainability. This is done by using the analytic hierarchy process (AHP hereafter), according to the comparison of the importance each student places on the criteria (Medineckiene et al. 2010). A cluster analysis identifies groups of students according to the distance between their preferences (Lee et al. 2014). Thus, the preferences of multiple evaluators are represented by only one dataset. These data correspond to the student profile and are the result of an aggregation method, such as the arithmetic mean. This way, the students' views of sustainability can be grouped.

In the second instance, the specifications of project alternatives must be appraised by students based on the chosen criteria. Generally, the prioritized project is the result of the combined valorization between the profiles and appraisal of the project alternatives. There are subjective factors that might affect the outcome, which justifies a sensitivity analysis that aims to ascertain how the outcome could have been affected in light of a possible variation in the appraisals. The students apply a sensitivity analysis, which focuses on the variation of the criteria scores for each profile (Wolters and Mareschal 1995). In this way, students analyze the possible changes in prioritization as a result of the different orientation profiles.

\section{Selection of criteria for sustainability}

Before starting the participatory process, a general framework for sustainability is needed to identify the best criteria for a certain case study. The sustainability criteria were identified through a literature review process that focused on international standards and consulted scientific papers. Given the considerations previously stated, a framework of sustainability can be proposed: (1) it takes into consideration impacts on the social, environmental and economic system; (2) it has been corroborated by international standards, such as the Global Reporting Initiative, the sustainable development framework of the United Nations and the Wuppertal Sustainability Indicators; and (3) their concepts have breadth and flexibility so that students can adapt the general framework and interrelate them with more specific indicators. This framework has been validated by experts (Labuschagne et al. 2005) and applied by different authors (Huang et al. 2012; Lang et al. 2007). In this way, Labuschagne et al. (2005) state the criteria of sustainability, presented in Table 1, which is used as an initial proposal in the practical implementation of this study.

Table 1. Reference criteria of sustainability used in implementing the method (adapted from Labuschagne et al. 2005).

\begin{tabular}{ccc}
\hline $\begin{array}{c}\text { Economic } \\
\text { Sustainability }\end{array}$ & $\begin{array}{c}\text { Environmental } \\
\text { Sustainability }\end{array}$ & $\begin{array}{c}\text { Social } \\
\text { Sustainability }\end{array}$ \\
\hline Financial Health & Air Resources & $\begin{array}{c}\text { Internal Human } \\
\text { Resources }\end{array}$ \\
\hline Economic & Water Resources & External Population \\
Performance & Land Resources & Stakeholder \\
\hline Financial Potential & Participation \\
\hline Trading & Mined Abiotic & Macro Social \\
Opportunities & Resources & Performance \\
\hline
\end{tabular}




\section{Practical implementation}

The selection of the multi-criteria analysis tool was based on the following three considerations: (1) the simplicity of operation and comprehension for use by a group of students; (2) the compatibility with methods for identifying decision-making profiles; and (3) the evidence of its application in construction. On this point, Alarcón (2005) established the AHP as a technique that provides the best possible reliability compared to other multi-criteria techniques in the context of sustainability assessment and the selection of their factors. Furthermore, the findings of Jato-Espino et al. (2014) present the AHP as one of the most frequently used techniques in the construction field. These considerations led to the use of the AHP as a sustainability assessment tool in this case.

Based on the reference criteria for infrastructure sustainability assessment (Table 1) and the use of the AHP, participatory prioritization and a sensitivity analysis, separated into three stages, were carried out. In the first stage, the representative profiles of the participants were obtained. In the second stage, the investment alternatives were evaluated with respect to the preference of each profile. And in the third stage, a sensitivity analysis measured the variability of the result in terms of a change in the profiles' preferences. This way, graduate students, acting as participants, contrasted their technical, ethical and personal judgments on sustainability.

Table 2 represents the breakdown structure in seven steps of this practical implementation, grouped into three stages, using nine classroom hours guided by a facilitator. This process was put into practice by two classes of graduate students enrolled in the Project Feasibility course (2014 and 2015) included in the Master of Planning and Management in Civil Engineering; this MSc degree applies a holistic managerial approach to construction from both production and business standpoints (Jiménez et al. 2011; Yepes et al. 2012; TorresMachí et al. 2013).

Table 3 shows the characterization of the students. The facilitator of the study was an instructor who has specialized in the assessment of construction projects and in sustainability, with six years of experience. He was also supervised by two senior professors. For both classes, the activity was graded according to a final report for each team, as well as a scoring rubric described later in section 5 . 
Table 2. The participatory process layout.

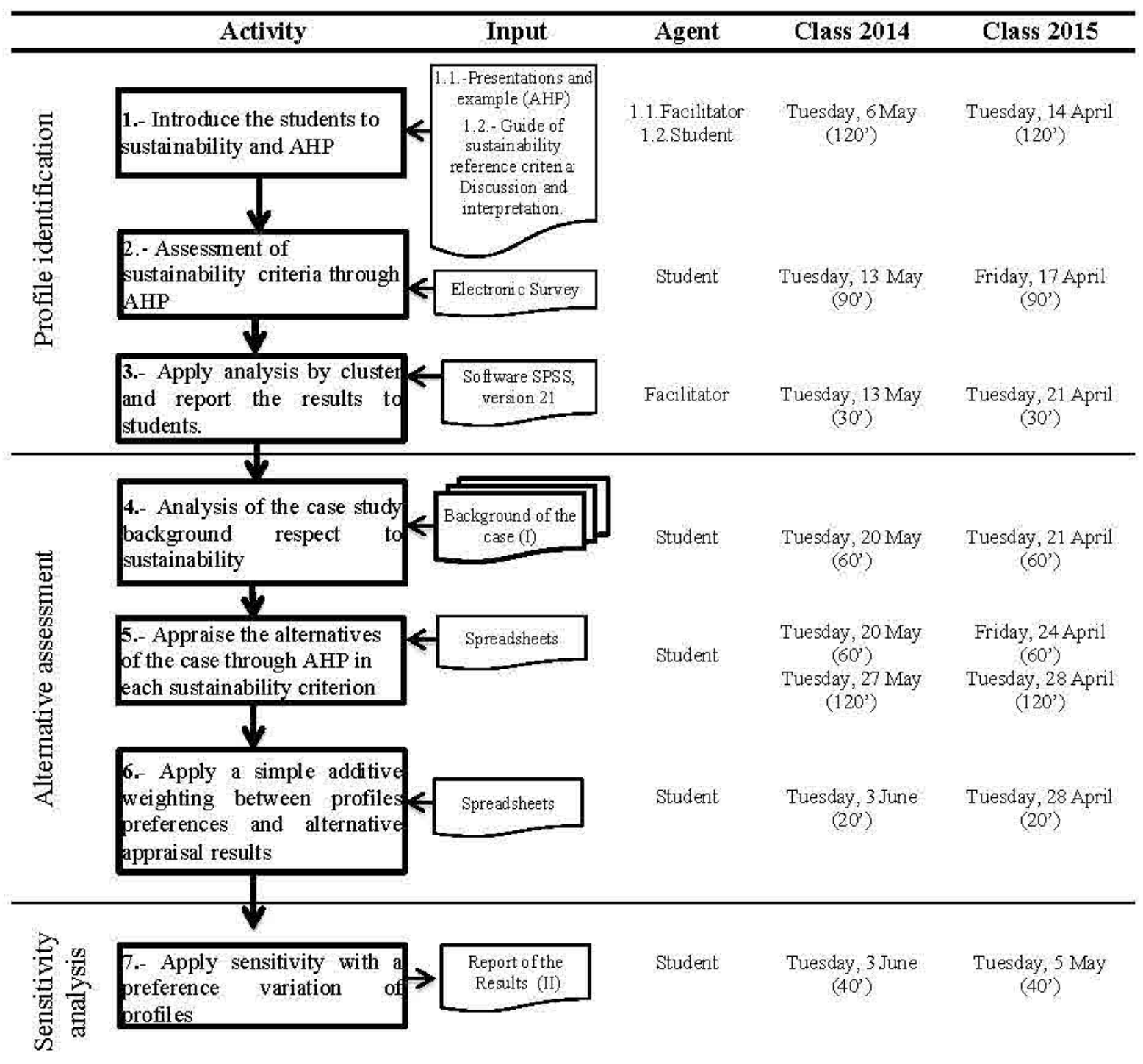

Note: (I) The background of the case is released to students one week in advance, through a virtual platform. The facilitator notifies students of the need to review the background. (II) Preparation time for delivery of the reports was a week: 
Table 3. Background of the process participants.

\begin{tabular}{|c|c|c|c|c|c|c|c|}
\hline \multirow{2}{*}{\multicolumn{2}{|c|}{ Number of students }} & \multicolumn{3}{|c|}{ Class of 2014} & \multicolumn{3}{|c|}{ Class of 2015} \\
\hline & & \multicolumn{3}{|c|}{36} & \multicolumn{3}{|c|}{29} \\
\hline \multirow[t]{5}{*}{ Age } & {$[20-23]$} & \multicolumn{3}{|c|}{$11.1 \%$} & \multicolumn{3}{|c|}{$6.9 \%$} \\
\hline & {$[24-28]$} & \multicolumn{3}{|c|}{$36.1 \%$} & \multicolumn{3}{|c|}{$41.4 \%$} \\
\hline & {$[28-32]$} & \multicolumn{3}{|c|}{$25.0 \%$} & \multicolumn{3}{|c|}{$41.4 \%$} \\
\hline & {$[32-36]$} & \multicolumn{3}{|c|}{$16.7 \%$} & \multicolumn{3}{|c|}{$6.9 \%$} \\
\hline & {$[36-39]$} & \multicolumn{3}{|c|}{$11.1 \%$} & \multicolumn{3}{|c|}{$3.4 \%$} \\
\hline \multirow[t]{3}{*}{ Origin } & Europe & \multicolumn{3}{|c|}{$50.0 \%$} & \multicolumn{3}{|c|}{$34.6 \%$} \\
\hline & Americas & \multicolumn{3}{|c|}{$41.7 \%$} & \multicolumn{3}{|c|}{$62.0 \%$} \\
\hline & Africa & \multicolumn{3}{|c|}{$8.3 \%$} & \multicolumn{3}{|c|}{$3.4 \%$} \\
\hline \multirow[t]{2}{*}{ Gender } & Male & \multicolumn{3}{|c|}{$30.6 \%$} & \multicolumn{3}{|c|}{$62.1 \%$} \\
\hline & Female & \multicolumn{3}{|c|}{$69.4 \%$} & \multicolumn{3}{|c|}{$37.9 \%$} \\
\hline \multirow[t]{5}{*}{ Profession } & Civil Engineer & \multicolumn{3}{|c|}{$55.6 \%$} & \multicolumn{3}{|c|}{$79.3 \%$} \\
\hline & Architect & & 11. & & & $3.5 \%$ & \\
\hline & Construction Eng. & & 5.6 & & & $10.3 \%$ & \\
\hline & Building Engineer & & 25. & & & $6.9 \%$ & \\
\hline & Other & & 2.7 & & & --- & \\
\hline Years of & {$[1-4]$} & & 69. & & & $44.8 \%$ & \\
\hline Experience & {$[4-7]$} & & 2.8 & & & $41.4 \%$ & \\
\hline & {$[7-10]$} & & 11. & & & $10.3 \%$ & \\
\hline & {$[10-13]$} & & 13 & & & $2.9 \%$ & \\
\hline & [14 and more] & & 2.8 & & & -- & \\
\hline Sustainability & & & Fiel & & & Field ${ }^{(}$ & \\
\hline & & 1 & 2 & 3 & 1 & 2 & 3 \\
\hline Prior & Part of a course & 5 & 3 & 0 & 21 & 17 & 17 \\
\hline Training & Full course & 10 & 2 & 0 & 1 & 1 & 1 \\
\hline & No training & & 50 & & & $17.2 \%$ & \\
\hline Experience & Yes & 6 & 3 & 0 & 11 & 2 & 3 \\
\hline & No & & 77. & & & $55.2 \%$ & \\
\hline
\end{tabular}

The implementation of the process that follows these steps is described next.

Step 1: The instructor acted as a facilitator who led the students during the early stages. The working dynamics involved the following activities:

- Basic concepts and the sustainability criteria regarding social, environmental and economic approaches (Table 1) were introduced.

- The general terms of the case study were explained. The students discussed and answered the following question: What are the sustainability criteria that best fit this case? The general focus of the sustainability criteria was analyzed. The students discussed possible additions or eliminations of these criteria.

- The multi-criteria analysis systems were presented. The methodological foundations of the AHP were deepened.

- Students carried out an example of the AHP implementation exercise, proposed and supervised by the facilitator.

Step 2: At this stage, each student acted as an expert and comparatively appraised the sustainability criteria. These appraisals comparatively assessed the AHP survey (Table 4). In this survey, the student was asked to appraise the sustainability criteria through hierarchical levels: first among the general sustainability dimensions and second among social, 
environmental and economic sustainability criteria, considered separately. The number of comparisons ("N") to be carried out was determined by Eq. 1 (Saaty 1987) according to the number of criteria (“a”) subject to comparison within the same hierarchical cluster.

$$
N=a \frac{(a-1)}{2}(\text { Eq. 1) }
$$

The AHP assessment system evaluates the level of importance for one criterion versus another using Saaty's fundamental scale on a ranking of 1 to 9 , in which " 1 " indicates equal importance and "9" indicates extremely important. This dynamic was used as an individual assessment, in which the student had to solve the survey and check the level of importance for sustainability criteria. The comparisons among hierarchical groups had to be coherent according to the consistency ratio established by Saaty (1980): from 5\% to $10 \%$.

Table 4. Extract of comparative appraisal survey (based on Saaty 1987).

\begin{tabular}{ll}
\hline \multicolumn{1}{c}{ Criteria Contrast } & $\begin{array}{l}\text { Assign an appraisal in the same order in which it } \\
\text { is announced: the least important criterion is } \\
\text { quantified as 1 - whereas the other is quantified } \\
\text { up to 9, taking Saaty's scale into account (1987) }\end{array}$ \\
\hline Social Sustainability versus Environmental Sustainability & $/$ \\
\hline Social Sustainability versus Economic Sustainability & $/$ \\
\hline Environmental Sustainability versus Social Sustainability & $/$ \\
\hline $\begin{array}{l}\text { Internal Human Resources versus External Local Population } \\
\text { (I) }\end{array}$ & $/$ \\
\hline Air Resources versus Water Resources \\
(II) \\
\hline $\begin{array}{l}\text { Financial Health versus Economic Performance } \\
\text { (III) }\end{array}$ \\
\hline $\begin{array}{l}\text { Note: (I) comparison among the rest of the social sustainability criteria; (II) comparison among the rest of the environmental sustainability criteria; and } \\
\text { (III) comprison among the rest of the economic sustainability criteria }\end{array}$
\end{tabular}

Step 3: At this stage, the activities leading to obtaining decision-making profiles were coordinated by the facilitator. Each survey was processed and a matrix for each group of criteria was comprised from the same hierarchical group, i.e., sustainability, economic sustainability, social sustainability and environmental sustainability. In each matrix, the intrinsic values were obtained, which corresponds to the partial weights each student confers on the criteria within its hierarchical cluster. Thus, the partial weight of each criterion on the second hierarchical level was weighted with the partial weight of the sustainability criterion from the first hierarchical level to which it belonged (social, economic and environmental level) in order to obtain the final weights of the sustainability criteria from each student (Saaty 1987).

The resulting weights from each survey indicated the order of importance that each student attributed to the final sustainability criteria. Based on those weights, a cluster analysis was performed according to the Ward (1963) method, with a measuring interval of Euclidean distance to the square and the support of statistical software SPSS v. 21. In general terms, Ward's method (1963) groups elements hierarchically to minimize the intra-group variation of a structure. The intra-group quadratic addition (IQA) corresponds to the sum of the IQA of each $k$ group; also, the IQA of group $k$ corresponds to the addition of deviations in all the criteria $(m)$ for all students $\left(n_{j}\right)$ within cluster $k$. The deviations are the result of the quadratic 
difference between the weight $(X)$ of criterion $i$ for each student $j$ who belongs to group $k$ and the average weight $(X)$ of criterion $i$ in group $k$, as reflected in Eq. 2 (Ward 1963).

$$
I Q A=\sum_{1}^{h} I Q A_{k} ; I Q A_{k}=\sum_{i=1}^{m} \sum_{j=1}^{n_{k}}\left(X_{i j k}-\bar{X}_{i k}\right)^{2}(\text { Eq. 2) }
$$

The selection of the number of clusters was determined based on the number of manageable profiles that did not increase variability within the clusters (Vila-Baños et al. 2014). Accordingly, Fig. 2 shows the Ward (1963) dendrogram: a layout that illustrates a squared Euclidean distance of five, confirming four groups for each case study with different orientations toward sustainability. For the 2014 class, the following profiles were identified: (1) social with an economic trend; (2) economic; (3) environmental with a social trend; and (4) environmental with an economic trend (Fig. 2 left). Meanwhile, for the 2015 class, the following profiles were identified: (A) financial, i.e. the student prefers to guarantee funding throughout the project life-cycle; (B) environmental with a social trend; (C) economic, i.e., the student prefers to ensure the economic profitability of the project; and (D) social with an environmental trend (Fig. 2 right). For both cases, the environmental trend is highlighted. The class of 2014 had a more homogeneous distribution than the 2015 class, because the environmental trend reached a differentiation (economic and social), whereas for the 2015 class, the economic dimension also reached a differentiation but in a more reduced group. The representative valuation of the sustainability criteria of each profile was the result of the arithmetic mean of the weights of the students that comprised each profile. The facilitator explained the analysis undertaken and the results obtained to the students, making public the profile to which each student belonged.


Fig.2. Identification of the trend on sustainability through the Ward dendrogram for the 2014 class (left) and the 2015 class (right) 
Step 4: Students were given the background of a real case, consisting of the assessment of infrastructure projects, addressed in collaborative teams. The discussion that began in Step 1 was deepened in order to determine the quantitative and qualitative indicators that justify the assessment of each alternative. Two case studies were implemented during the academic years 2013-2014 (see Fig. 3) and 2014-2015. Both cases considered the life-cycle assessment: not only design and construction, but also operation. The information from both case studies is shown in Table 5. The teams were organized taking into consideration: (a) the practicality of the activity according to a limited execution time, (b) the facilitator advisory capacity, (c) the participation of the entire group, and (d) the representation of every team profile considering all or most of the profiles of the students on the team. Fig. 2 shows the distribution of four profiles in each course. The distribution of profiles in collaborative teams is specified in Table 6 ; the teams were configured according to the proximity of its members' preferences.



Fig 3a: Alternative 0 (no-project) for case study 1

Fig 3b: Alternative 1 for case study 1

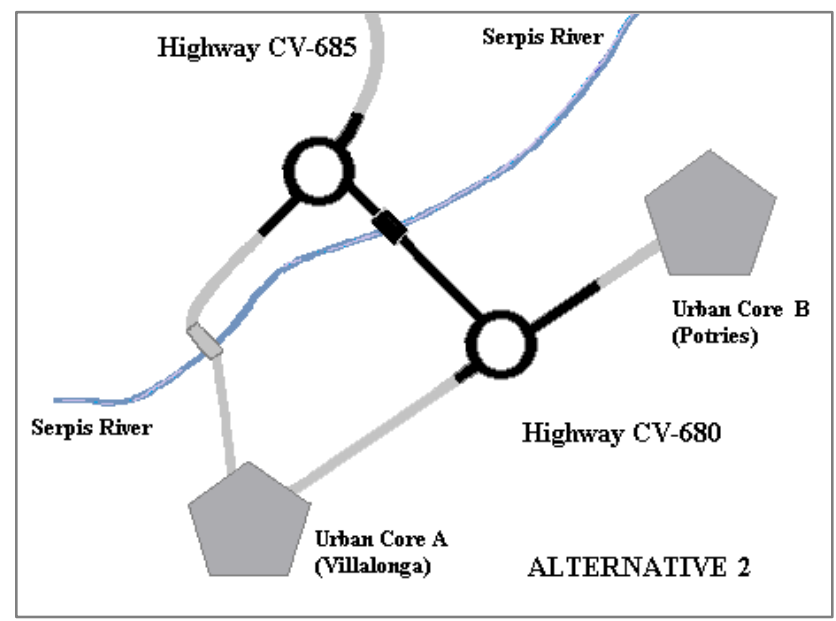

Fig 3c: Alternative 2 for case study 1 
Table 5. Background of case studies 1 and 2

\begin{tabular}{|c|c|}
\hline Case Study 1 (Class 2014) & Case Study 2 (Class 2015) \\
\hline $\begin{array}{l}\text { Local Information. } \\
\text { Town A has } 4,350 \text { inhabitants and an area of } 43.3 \mathrm{~km}^{2} \text {. It has a } 10- \\
\text { year population growth of } 0.7 \% \text {. Its unemployment rate is } 9.83 \% \text {. } \\
\text { Town B has } 987 \text { inhabitants and an area of } 3.1 \mathrm{~km}^{2} \text {. It has had no } \\
\text { population growth in the last decade. Its unemployment rate is } \\
8.51 \% \text {. } \\
\text { Both urban areas have civic spaces, cultural heritage buildings and } \\
\text { basic education and health services. Their main economic } \\
\text { activities are the agri-food industry, handmade ceramics and, to a } \\
\text { lesser extent, rural tourism. }\end{array}$ & $\begin{array}{l}\text { Local Information. } \\
\text { The alternatives are located in mid-sized towns (around 20,000 } \\
\text { people). The main productive activities are: food industry, } \\
\text { agricultural and livestock transformation, crafts and cultural tourism. } \\
\text { In the sector, the population growth rate does not exceed } 0.9 \% \text {. }\end{array}$ \\
\hline $\begin{array}{l}\text { Alternative 0: } \\
\text { Minimum travel distance of } 4.53 \mathrm{~km} \text { and crosses Town A. } \\
\text { Projected traffic: CV-685 2500 / CV680: } 8000 \text { vehicles/day. } \\
\text { Average speed: CV-685: } 45 \mathrm{~km} / \mathrm{hr} \text { / / CV680: } 45 \mathrm{~km} / \mathrm{hr} \text {. } \\
\text { Hazard index: CV-685: } 13 \text { / CV680: 7.1 } \\
\text { Death rate: CV-685 0.7 / CV680 0.5 } \\
\text { Operation costs (30 years): €623,749.00 }\end{array}$ & $\begin{array}{l}\text { Alternative M1: } \\
\text { Project the retaining wall of } 118 \mathrm{~m} \text { long with a deadline of } 5 \text { months } \\
\text { and an estimated hiring of } 28 \text { people. During construction, electrical } \\
\text { and sanitation services need to be scheduled. The value of bidding } \\
\text { reaches } € 252,129 \text {, with an allocation to health and safety costs of } \\
1.05 \% \text {. This finished in pigmented concrete, in line with the urban } \\
\text { regulations of the residential area. } 283 \text { people were direct } \\
\text { beneficiaries in the short-term. }\end{array}$ \\
\hline $\begin{array}{l}\text { Alternative 1: } \\
\text { Minimum travel distance of } 4.53 \mathrm{~km} \\
\text { Projected traffic CV-685 2500 / CV-680: } 8000 \text { vehicles/day. } \\
\text { Average speed: CV-685: } 75 \mathrm{~km} / \mathrm{hr} \text {. / CV-680: } 90 \mathrm{~km} / \mathrm{hr} \text {. } \\
\text { Hazard index: CV-685: } 9.5 \text { / CV-680: } 7.1 \\
\text { Death rate: CV-685 0.55 / CV-680 0.5 } \\
\text { Operation costs ( } 30 \text { years): } € 1,205,120.00 \\
\end{array}$ & $\begin{array}{l}\text { Alternative M2: } \\
\text { Project the retaining wall of } 86 \mathrm{~m} \text { in length with a deadline of four } \\
\text { months and an estimated hiring of } 13 \text { people. During construction, } \\
\text { electrical services need to be intervened. The value of bidding reaches } \\
€ 78,476 \text {, with an allocation to health and safety costs of } 0.57 \% \text {. } 166 \\
\text { people were direct beneficiaries in the short-term. }\end{array}$ \\
\hline $\begin{array}{l}\text { Alternative 2: } \\
\text { Minimum travel distance of } 2.4 \mathrm{~km} \\
\text { Projected traffic CV-685 } 2500 \text { / CV-680: } 10328 \text { vehicles/day } \\
\text { Average speed: CV-685: } 75 \mathrm{~km} / \mathrm{hr} \text {. / CV-680 } 100 \mathrm{~km} / \mathrm{hr} \text {. } \\
\text { Hazard index: CV-685: 7.1 / CV-680: } 4.5 \\
\text { Death rate: CV-685 0.5 / CV-680: } 0.4 \\
\text { Operation costs (30 years): } € 4,018,524.00\end{array}$ & $\begin{array}{l}\text { Alternative M3: } \\
\text { Breakwater retaining wall } 45 \mathrm{~m} \text { in length, } 6 \mathrm{~m} \text { high with a deadline of } \\
2 \text { months and an estimated recruitment eight people. Their level of } \\
\text { earthmoving reaches } 1148 \mathrm{~m}^{3} \text { and considers reuse of excavation } \\
\text { material. The value of bidding reaches } € 52,427 \text {, with an allocation to } \\
\text { health and safety costs of } 2.26 \% \text {. The influence area covers a } \\
\text { population of } 510 \text { people. }\end{array}$ \\
\hline
\end{tabular}

Step 5: In this step, students analyzed the alternatives according to the sustainability criteria agreed to in Step 1 as well as the indicators produced in Step 4. To this end, the team valued the relative level of importance for each of the alternatives based on a comparison by pairs that applied the Saaty scale. Each team presented a unique output of their appraisals through a comparison matrix for each sustainability criterion. The processing of the scores of each matrix provided the intrinsic value, which represents the relative weight of each alternative compared to the others for every sustainability criterion (Saaty 1987). This exercise was applied to the construction and operation phases of the infrastructure life-cycle.

Step 6: This step was based on the output of the appraisal of sustainability criteria for each profile and the weights of the alternatives for every sustainability criterion. Each alternative was weighted by appraising the corresponding criteria, according to the profile assigned to each team. Thus, all contributions of this alternative to sustainability were added up. This way, the overall weight of each alternative was obtained, which included consideration of all criteria according to the background of alternatives and the students' value judgments.

This exercise was applied to the construction and operation phases of each infrastructure lifecycle. In the construction phase of case study 1, the results of the nine teams gave higher overall weight to Alternative 0 , while there was no clear second choice. Meanwhile, during the operation phase, the preferences were not uniform, and in some cases, the vagueness in the consideration of the project characteristics assessment made it difficult to differentiate among the alternatives. For both life-cycle phases in case study 2, prioritizations differed in accordance with each team's profile. The results for both classes are displayed in Table 6. On the other hand, Table 7 shows the main considerations that students took into account in their decision-making process. 
Table 6. Prioritized projects for the student teams.

\begin{tabular}{|c|c|c|c|c|c|c|}
\hline \multirow[t]{3}{*}{ Team } & \multicolumn{3}{|c|}{ Case 1 (Class 2014) } & \multicolumn{3}{|c|}{ Case 2 (Class 2015) } \\
\hline & \multirow{2}{*}{$\begin{array}{c}\text { Team members' } \\
\text { profiles }\end{array}$} & \multicolumn{2}{|c|}{ Alternative / Weight } & \multirow{2}{*}{$\begin{array}{c}\text { Team members' } \\
\text { profiles }\end{array}$} & \multicolumn{2}{|c|}{ Alternative / Weight } \\
\hline & & Construction & Operation & & Construction & Operation \\
\hline 1 & 4 members Profile 1 & $\begin{array}{l}\text { 1st place } \\
\text { Alt-0 (0.46) } \\
\text { 2nd place } \\
\text { Alt-2 (0.31) } \\
\end{array}$ & $\begin{array}{l}\text { 1st place } \\
\text { Alt-2 (0.41) } \\
\text { 2nd place } \\
\text { Alt-1 (0.38) } \\
\end{array}$ & 4 members Profile A & $\begin{array}{l}\text { 1st place } \\
\text { Alt-M1 (0.42) } \\
\text { 2nd place } \\
\text { Alt-M2 (0.35) }\end{array}$ & $\begin{array}{l}\text { 1st place } \\
\text { Alt-M2 (0.41) } \\
\text { 2nd place } \\
\text { Alt-M3 (0.34) } \\
\end{array}$ \\
\hline 2 & 4 members Profile 1 & $\begin{array}{l}\text { 1st place } \\
\text { Alt-0 (0.44) } \\
\text { 2nd place } \\
\text { Alt-2 }(0.30) \\
\end{array}$ & $\begin{array}{l}\text { 1st place } \\
\text { Alt-2 (0.40) } \\
\text { 2nd place } \\
\text { Alt-1 (0.39) } \\
\end{array}$ & 4 members Profile A & $\begin{array}{l}\text { 1st place } \\
\text { Alt-M1 (0.45) } \\
\text { 2nd place } \\
\text { Alt-M2 (0.36) }\end{array}$ & $\begin{array}{l}\text { 1st place } \\
\text { Alt-M2 (0.43) } \\
\text { 2nd place } \\
\text { Alt-M3 (0.34) } \\
\end{array}$ \\
\hline 3 & 4 members Profile 2 & $\begin{array}{l}\text { 1st place } \\
\text { Alt-0 (0.45) } \\
\text { 2nd place } \\
\text { Alt-1 }(0.36) \\
\end{array}$ & $\begin{array}{l}\text { 1st place } \\
\text { Alt-1 (0.47) } \\
\text { 2nd place } \\
\text { Alt-2 (0.35) } \\
\end{array}$ & 4 members Profile B & $\begin{array}{l}\text { 1st place } \\
\text { Alt-M1 (0.33) } \\
\text { 2nd place } \\
\text { Alt-M2 (0.33) }\end{array}$ & $\begin{array}{l}\text { 1st place } \\
\text { Alt-M2 (0.43) } \\
\text { 2nd place } \\
\text { Alt-M3 (0.38) } \\
\end{array}$ \\
\hline 4 & $\begin{array}{c}3 \text { members Profile } 2 \\
\text { and } 1 \text { member } \\
\text { Profile } 4\end{array}$ & $\begin{array}{l}\text { 1st place } \\
\text { Alt-0 (0.54) } \\
\text { 2nd place } \\
\text { Alt-1 }(0.30) \\
\end{array}$ & $\begin{array}{l}\text { 1st place } \\
\text { Alt-1 (0.50) } \\
\text { 2nd place } \\
\text { Alt-2 (0.35) } \\
\end{array}$ & 5 members Profile B & $\begin{array}{l}\text { 1st place } \\
\text { Alt-M1 (0.36) } \\
\text { 2nd place } \\
\text { Alt-M2 (0.34) }\end{array}$ & $\begin{array}{l}\text { 1st place } \\
\text { Alt-M2 (0.45) } \\
\text { 2nd place } \\
\text { Alt-M3 (0.38) } \\
\end{array}$ \\
\hline 5 & 4 members Profile 3 & $\begin{array}{l}\text { 1st place } \\
\text { Alt-0 (0.59) } \\
\text { 2nd place } \\
\text { Indefinite } \\
\end{array}$ & $\begin{array}{l}\text { 1st place } \\
\text { Alt-2 (0.40) } \\
\text { 2nd place } \\
\text { Alt-0 (0.34) } \\
\end{array}$ & 4 members Profile B & $\begin{array}{l}\text { 1st place } \\
\text { Alt-M1 (0.34) } \\
\text { 2nd place } \\
\text { Alt-M2 (0.32) }\end{array}$ & $\begin{array}{l}\text { 1st place } \\
\text { Alt-M2 (0.43) } \\
\text { 2nd place } \\
\text { Alt-M1 (0.39) } \\
\end{array}$ \\
\hline 6 & 4 members Profile 3 & $\begin{array}{l}\text { 1st place } \\
\text { Alt-0 (0.56) } \\
\text { 2nd place } \\
\text { Alt-1 }(0.24) \\
\end{array}$ & $\begin{array}{l}\text { 1st place } \\
\text { Alt-2 (0.36) } \\
\text { 2nd place } \\
\text { Indefinite } \\
\end{array}$ & 4 members Profile C & $\begin{array}{l}\text { 1st place } \\
\text { Alt-M2 (0.44) } \\
\text { 2nd place } \\
\text { Alt-M1 (0.33) }\end{array}$ & $\begin{array}{l}\text { 1st place } \\
\text { Alt-M1 (0.40) } \\
\text { 2nd place } \\
\text { Alt-M2 (0.35) } \\
\end{array}$ \\
\hline 7 & 4 members Profile 3 & $\begin{array}{l}\text { 1st place } \\
\text { Alt-0 (0.58) } \\
\text { 2nd place } \\
\text { Alt-1 }(0.27) \\
\end{array}$ & $\begin{array}{l}\text { 1st place } \\
\text { Indefinite } \\
\text { 2nd place } \\
\text { Indefinite } \\
\end{array}$ & $\begin{array}{c}1 \text { member Profile B } \\
\text { and } 3 \text { members } \\
\text { Profile D }\end{array}$ & $\begin{array}{l}\text { 1st place } \\
\text { Alt-M1 (0.47) } \\
\text { 2nd place } \\
\text { Alt-M2 (0.27) }\end{array}$ & $\begin{array}{l}\text { 1st place } \\
\text { Alt-M3 (0.46) } \\
\text { 2nd place } \\
\text { Alt-M2 (0.40) }\end{array}$ \\
\hline 8 & 4 members Profile 4 & $\begin{array}{l}\text { 1st place } \\
\text { Alt-0 (0.61) } \\
\text { 2nd place } \\
\text { Alt-1 }(0.24) \\
\end{array}$ & $\begin{array}{l}\text { 1st place } \\
\text { Alt-1 (0.37) } \\
\text { 2nd place } \\
\text { Alt-2 (0.34) } \\
\end{array}$ & & & \\
\hline 9 & 4 members Profile 4 & $\begin{array}{l}\text { 1st place } \\
\text { Alt-0 (0.60) } \\
\text { 2nd place } \\
\text { Alt-1 }(0.24) \\
\end{array}$ & $\begin{array}{l}\text { 1st place } \\
\text { Alt-1 (0.39) } \\
\text { 2nd place } \\
\text { Alt-2 (0.37) }\end{array}$ & & & \\
\hline
\end{tabular}

Table 7. The key considerations that students took into account.

\section{Case 1 (Class of 2014)}

Case 2 (Class of 2015)

- Alternative 0 implies a lower operating cost, and does not The M1 alternative:

generate institutional, environmental and social interventions. - During construction, it supports recruitment in an area with higher However, the operation is not a viable alternative that provides a unemployment

solution in the long term.

- It strengthens the use of materials and hiring of services in the area

- The project stems from a process of public consultation with public vote organized by the municipality.

- Its construction is associated with an "Urban Rehabilitation" program with a construction subsidy of $€ 151,732$.

- It is the alternative that means more economic movement and for a longer period.

- It has a better use of public resources as a function of their maintenance costs and number of beneficiaries.

- Alternative 1 satisfies the need and is more profitable in the long The M2 alternative:

term in terms of costs of operation and economic benefits for - It produces a lower volume of solid waste to be disposed of. drivers.

- According to Spanish legislation and the level of impact, it does

- The estimate of the set of energy contained and $\mathrm{CO}_{2}$ generation not require an environmental impact assessment.

for the construction of Alternative 1 is less than for Alternative 2 - The volume and type of project involve less use of alternative - Alternative 1 involves lower volume of earth moving and solid energy and mineral resources for its construction.

waste generation.

- The risk of delayed construction payments associated with its -Alternative 1 has a smaller and mitigated impact on the Serpis promoter is the lowest among the three alternatives. This ensures riverbed. It modifies the existing using of the space that was compliance with financial commitments to suppliers involved in the intervened in the construction of the first bridge. project. 


\begin{tabular}{|c|c|}
\hline & $\begin{array}{l}\text { - Maintenance activities are manual without the use of equipment } \\
\text { that uses energy or water and without equipment that emits gases. } \\
\text { - It boasts improved accessibility and connectivity of people, safety, } \\
\text { the environment, rural tourism and other business relationships. }\end{array}$ \\
\hline $\begin{array}{l}\text { - The high level of recruitment and duration of Alternative } 2 \\
\text { promote job stability during construction. } \\
\text { - Alternative } 2 \text { provides a design with improved security to the user } \\
\text { during operation. } \\
\text { - Alternative } 2 \text { promotes traffic flow. This supports the local } \\
\text { economy of industry and generates indirect employment, which is } \\
\text { especially desirable when the economic crisis in Spain is } \\
\text { considered. } \\
\text { - Alternative } 2 \text { favors the decongestion of Town A, which means } \\
\text { lower sensory impact on the population (noise and landscape) and } \\
\text { safety of their urban environment. } \\
\text { - Alternative } 2 \text { does not require expropriation. The lots are provided } \\
\text { by the municipality. }\end{array}$ & $\begin{array}{l}\text { The M3 alternative: } \\
\text { - It encourages a reduced generation of } \mathrm{CO}_{2} \text { (less consumption of } \\
\text { concrete) and lower water consumption. } \\
\text { - Its location means lower impact on affected services and } \\
\text { undesirable sensory stimuli. } \\
\text { - The project is not associated with urban gardening works. Also, } \\
\text { maintenance costs are lower and the use of water is required. } \\
\text { - The wall supports the road that links the two rural locations. Its } \\
\text { construction strengthens the safety of drivers. } \\
\text { - It strengthens tourism between rural localities. } \\
\text { - Its design in stone masonry is harmonious with the surroundings. }\end{array}$ \\
\hline
\end{tabular}

Step 7: The students analyzed the sensitivity of the decision-making with respect to the profile change. It was made through the variation in the weights of the criteria. Analogous to Step 6, each team incorporated the assessment criteria regarding the remaining three profiles to identify the possible differentiation in the preference for alternatives during the construction and operation phases. Students concluded their findings before they delivered the report on their results. These outputs were checked by the facilitator through Kendall's statistical test to identify the correlation of the teams regarding the prioritization of alternatives for each profile. During the construction phase, Alternative 0 was selected as the first priority by all teams in the 2014 class, whereas Alternative M1 was chosen by teams 6 and 7 in the 2015 class -its prioritization being significant according to the statistical test. As for the operation phase, Table 8 shows an important variability in the prioritization of alternatives, but the agreement at the $95 \%$ level of confidence remains significant.

Table 8: Sensitivity analysis per profile at the stage of operation of the infrastructure for both case studies.

\begin{tabular}{|c|c|c|c|c|c|c|}
\hline $\begin{array}{l}\text { Operation Stage } \\
\text { Class of } 2014\end{array}$ & & Alternative 0 & Alternative 1 & Alternative 2 & $\begin{array}{l}\text { W's } \\
\text { Kendal }\end{array}$ & $\begin{array}{l}\text { Asymptotic } \\
\text { Sign. }\end{array}$ \\
\hline Profile 1 & $\begin{array}{l}\text { Prioritization } \\
\text { Ranking }\left[1^{\mathrm{st}}-3^{\mathrm{rd}}\right]\end{array}$ & 3.00 & 1.89 & 1.11 & .901 & .000 \\
\hline Profile 2 & $\begin{array}{l}\text { Prioritization } \\
\text { Ranking }\left[1^{\text {st }}-3^{\text {rd }}\right]\end{array}$ & 3.00 & 1.00 & 2.00 & 1.000 & .000 \\
\hline Profile 3 & $\begin{array}{l}\text { Prioritization } \\
\text { Ranking }\left[1^{\mathrm{st}}-3^{\mathrm{rd}}\right]\end{array}$ & 2.44 & 2.56 & 1.00 & .753 & .001 \\
\hline Profile 4 & $\begin{array}{l}\text { Prioritization } \\
\text { Ranking }\left[1^{\text {st }}-3^{\text {rd }}\right]\end{array}$ & 3.00 & 1.22 & 1.78 & .827 & .001 \\
\hline $\begin{array}{l}\text { Operation Stage } \\
\text { Class of } 2015\end{array}$ & & $\begin{array}{l}\text { Alternative } \\
\text { M1 }\end{array}$ & $\begin{array}{l}\text { Alternative } \\
\text { M2 }\end{array}$ & $\begin{array}{c}\text { Alternative } \\
\text { M3 }\end{array}$ & & \\
\hline Profile A & $\begin{array}{l}\text { Prioritization } \\
\text { Ranking }\left[1^{\mathrm{st}}-3^{\mathrm{rd}}\right]\end{array}$ & 2.99 & 1.03 & 2.01 & .810 & .001 \\
\hline Profile B & $\begin{array}{l}\text { Prioritization } \\
\text { Ranking }\left[1^{\text {st }}-3^{\text {rd }}\right]\end{array}$ & 2.25 & 1.21 & 1.91 & .650 & .021 \\
\hline Profile C & $\begin{array}{l}\text { Prioritization } \\
\text { Ranking }\left[1^{\mathrm{st}}-3^{\mathrm{rd}}\right]\end{array}$ & 1.14 & 2.01 & 2.81 & .863 & .001 \\
\hline Profile D & $\begin{array}{l}\text { Prioritization } \\
\text { Ranking }\left[1^{\mathrm{st}}-3^{\mathrm{rd}}\right]\end{array}$ & 2.60 & 1.69 & 1.30 & .827 & .000 \\
\hline
\end{tabular}

\section{Assessment of the process}

The assessment of the educational process was completed based on the development and application of two measuring instruments: a scoring rubric that assesses the level of achievement for each team and a survey to measure the overall effectiveness of the process. 
Both instruments were developed through a focus group composed of seven professors in the construction management field at the Universitat Politècnica de València, including the authors of this paper.

The scoring rubric was applied to each team's output. Examination and appraisal of this report involved four aspects with a corresponding score according to the level of efficiency achieved by each team:

- $\quad$ procedure and method (20\%);

- $\quad$ analysis of alternatives and their influence on sustainability (30\%);

- interpretation of the impact of human appraisal in decision-making and sensitivity analysis (30\%); and

- $\quad$ synthesis of the outcomes, as well as personal comments (20\%).

The results of the weighting of these aspects show how achievement was reflected in each team. The learning outputs achieved by all students exceed $65 \%$ and $60 \%$ for the 2014 and 2015 classes, respectively. The best assessed aspect of the rubric is "means and methods", whereas the "analysis of alternatives" and the association of qualitative indicators required more attention from the students. However, in every case, the items of the scoring rubric achieved more than 50\% acceptance. Furthermore, the background of the students was compared with the learning outputs in order to identify any influence on the process. In each case, not significant correlations were identified.

Similarly, the background of the students was checked with the cluster. A statistically significant (95\% confidence level) relationship was identified for the 2015 class between the previous training in sustainability and Profile B (environmental with social tendency). In this regard, Table 9 shows the measures of central tendency regarding the learning outputs for the students in both classes, which takes into account their previous experience and training in sustainability.

Table 9: Learning outcomes through the application of the assessment rubric.

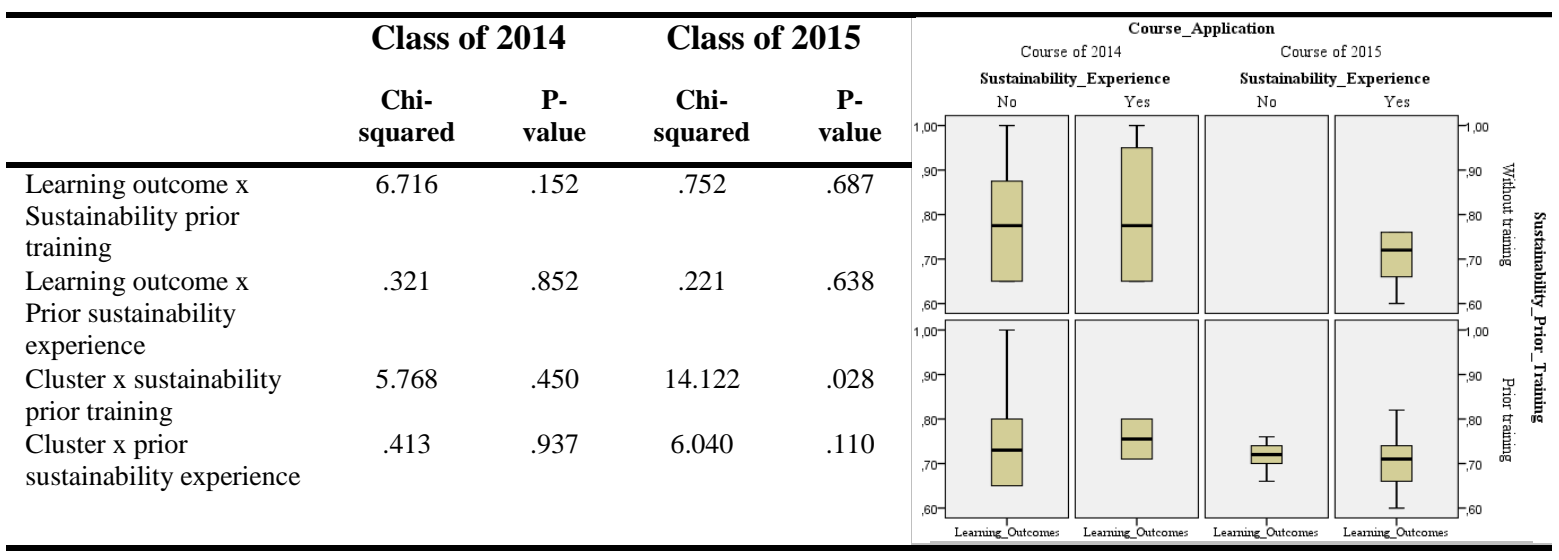

On the other hand, the students were surveyed once the work was completed and the same day that the report was submitted for evaluation. They had to evaluate six statements based on a Likert scale from 1 (strongly disagree) to 10 (completely agree). The statements were grouped into two constructs, as follows: 
Construct 1: Relevance of learning method for measuring sustainability in infrastructure:

P1.- $\quad$ The content and application of the method studied was significant for professional development.

P2.- $\quad$ The set of developed activities were adequate for achieving the learning.

P3.- $\quad$ The AHP method is an appropriate system in decision-making.

Construct 2: Compressibility of the interrelationship of human preferences and characteristics of the infrastructure in sustainable decision-making:

P4.- I understood how appraisal of human preferences affects sustainable decisionmaking.

P5.- I understood how the characteristics of a project interact with people's feelings and preferences.

P6.- I understood how the characteristics of a project influence sustainability.

To measure internal consistency, the reliability of each construct was determined by using Cronbach's alpha (Table 9). For each case, the alpha falls into the category of good (greater than 0.8) (George and Mallery 2003). The results of the questionnaire applied to both classes are presented in Table 10.

Table 10: Results of the learning process through the application of a survey.



\section{Discussion}

Regarding the implementation of the process, it should be noted that the multi-criteria analysis technique (the AHP) was adequate according to the terms of practicality, simplicity of methodological management, comprehensibility and applicability according to the students' statements (Table 10); this concurs with the findings of Jato-Espino et al. (2014), who state that AHP is very suitable for decision-making problems involving economic, environmental, and social facets. The group structure of the course was appropriate for developing the educational process. The configuration of mixed teams (team 4 in class 2014 and team 7 in class 2015) did not reveal any differences in the alternative prioritization in relation to other teams whose profiles had a similar or equivalent association.

For the purposes of this paper, the method is suitable for identifying the profile of students in terms of their preference for the sustainability criteria; this method was developed using a cluster analysis, as successfully performed by Nelson et al. (2015) for identifying motivational profiles. In both the 2014 and 2015 classes, there was a clear differentiation between the economic profile and the rest of the profiles as well as an environmental trend 
(Fig. 2). Previous research (Summers et al. 2004; Valdés-Vásquez and Klotz 2011; Watson et al. 2013) has highlighted the fact that the environmental (Medineckiene et al. 2010) and economic (Levitt 2007) facets of sustainability are more widely acknowledged. For the method proposed in this paper, however, it is not advisable to establish fewer than four profiles as doing so would increase the internal heterogeneity of preference in decisionmaking, and a number greater than four tends not to be very practical and in some cases is difficult to differentiate (Vila-Baños et al. 2014).

Concerning the influence of the profiles on decision-making, it was found that in the 2014 class, for the short term in the construction phase, the no-project alternative was preferred by all profiles because non-intervention is collectively the largest contributor option to the criteria of social, environmental and economic sustainability; this is consistent with other studies (Bilec et al. 2010; Sierra et al. 2015) that note a major impact of the construction phase on sustainability. In this stage, the enhancing Alternatives 1 and 2 do not yet provide evidence of their major contributions to sustainability. In the same sense, but in a second prioritization, employment prospects interact with the social Profile 1 , assigning a higher preference to the project that contributes the most to this criterion (Alternative 2). For other cases, Alternative 1 is the second option. In the 2015 class, the construction phase of the alternative M1 satisfies the conditions of most of the teams. This has social characteristics that exceed the rest of the alternatives (procurement, socioeconomic contributions and citizen involvement); it attracts the preferences of profiles B and D. Furthermore, it has associated financial subsidies that attract Profile A. During the operation phase, Alternative M2 is preferred by Profile B because of its environmental potential, and by Profile A because of the indirect contribution to the local economy. On the other hand, the financial profitability and the contribution to the local community of Alternative M1 attract the preference of profiles C and $\mathrm{D}$, respectively.

The main arguments from the students confirm the final selection. Table 7 displays a sample of arguments according to the chosen alternative. Terms such as employability, quality of life, occupational safety and accidents are named by the teams with social focus (Labuschagne et al. 2005; Valdés-Vásquez and Klotz 2011), whereas terms such as pollution, contained energy, waste, hydraulic resource or ecosystem are highlighted by the teams with an environmental tendency (Huang et al. 2012; Kucukvar et al. 2014). Furthermore, concepts such as net present value, cost, investment, maintenance, use of public resources and economic crisis are mentioned by teams with an economic focus (FHWA 2003, Torres-Machí et al. 2014).

In the long term, different preference alternatives are detected in the operation phase. In the sensitivity analysis (Table 8) the statistical consistency of project priority according to the profile of preference was tested. Given the variation in the preference for sustainability, the consistency coefficients, for both classes, determine a significant correlation regarding the change in a sustainability profile. In this case, in general terms, profiles with some economic influence are inclined toward the alternative that involves greater influence on profitability (Alternative 1). Those profiles that feature some social influence focus on an alternative with a greater impact on community criteria (Alternative 2). This way, the characteristics of the alternatives lead to a preference for a specific alternative according to a given profile; for example, some authors (Dwyer and Byrne 2010; Byrne et al. 2013) assert that engineers with more knowledge and skills in environmental facets identify attributes related to their jobs only in the environmental category. 
When examining individual results in the operation phase, it was necessary in some teams to clarify the analysis of the appraisal of alternatives, especially in social sustainability criteria, in order to identify differences between alternatives (teams 2 and 7 in the 2014 class) as none of the 2014 students had undergone previous training in sustainability. Valdés-Vásquez and Klotz (2011) state that social sustainability is the dimension of sustainability least considered in engineering.

It is important to highlight that the assessment of the characteristics of the alternatives is not free of subjectivities despite the correct interpretation, due to the qualitative aspects and the relative precision of the Saaty scale (Arroyo et al. 2015). This produced close results that were difficult to differentiate in prioritization. However, some previous contributions emphasize that students should be challenged with ill-defined scenarios (Bucciarelli et al. 2000) or with self-defined learning goals (Steiner and Posch 2006; Lehmann et al. 2008) during their academic career to be able to address the uncertainty of many real engineering problems, "particularly those in the social context" (Bucciarelli et al. 2000, p.142). The selection of a unique alternative in a participatory environment with different profiles is facilitated, considering that other alternatives are close to meeting the requirements and it is, therefore, easier to reach a consensus. In an educational scenario, this is normal because the students are not experts; thus, the role of the facilitator is key in guiding and contextualizing the case study to attain fruitful active learning (Prince 2004, Boks and Diehl 2006).

The evaluation system measured the quality of the processes developed by the students according to the scoring rubric; this same technique has been proposed by other authors (McCorminck et al. 2015) to assess students' learning. Through this tool, $100 \%$ of the teams reached a level of achievement of learning outcomes over $60 \%$. It is worth mentioning that, even though the class of 2014 did not undergo previous training in social sustainability, $67 \%$ of the students reached a level of learning above $70 \%$. In this context, both classes corroborated the independence between the students' background and the level of learning achieved during implementation of the method. Meanwhile, the results of the student survey (Table 10) show the relevance of the AHP method in their profession and for successfully learning about sustainability. Approval fluctuated in the range of 6.0 to 9.0 at a $95 \%$ confidence level in an ascending approval scale from 1 to 10 . At the higher levels of approval, students stated that the method allowed them to understand the interrelationship of human preferences and characteristics of an infrastructure for making sustainable choices. The approval level fluctuated in the range of 7.1 to 10.0 at a $95 \%$ confidence level. As stated previously, this finding aligns with previous research (Jato-Espino et al. 2014), which asserts that AHP is not only the most popular tool for decision-making but it is also the most robust and reliable.

Nonetheless, the authors have established some limitations of the method:

- The study needs to guarantee a minimum level of professional maturity in the students, so they can understand the construction processes. To this point, other authors (Bucciarelli et al. 2000; Lehmann et al. 2008; Du et al. 2013) underline the relationship between academic and professional facets as a key factor for a sustainable education.

- The study needs to guarantee a minimum number of students (at least 20) in order to form teams that are representative of the profiles regarding sustainability.

- The facilitator must have in-depth knowledge about not only the construction processes but also the many facets of sustainability, as previously noted by Boks and Diehl (2006). 
- The AHP relates criteria that are under the dominance of each sustainability dimension (environmental, economic and social) and takes into account only the direct effect (first order) that each infrastructure exerts on each criterion. An extension of the method implies the use of a tool that allows the interaction of the criteria with highorder effects. This is possible by using an Analytical Neural Process (Saaty and Vargas 2006). However, its implementation would require a technological background, more training time and work by the student on the activities involved.

\section{Conclusions}

Outcomes show that this proposal was appropriate for identifying the orientation in decisionmaking by graduate students regarding sustainability issues. Also, the need to clarify assessments of social criteria in alternative projects in order to generate significant differences in the contribution to sustainability was identified. Thus, the development of the case studies and their evaluation allowed the student to undertake a critical analysis and demonstrate an understanding how their personal values and sets of clusters influence the selection of a project.

In this context and according to the evidence of the results of these application cases, it was found that the profiles of evaluators or participants could influence the outcome of prioritization among a set of alternatives. In this sense, the method has promoted the learning of sustainability particularly, understanding the influence of the infrastructure characteristics and participant preferences in the results of the decisions made regarding sustainability.

The main limitations of the method are the need to train the facilitator in sustainability and construction processes, minimum previous professional experience of the students, as well as the considerations of only the direct impacts of infrastructure in the built environment. The transgression of these aspects does not guarantee the effectiveness of students' learning.

Future lines of research could focus on finding active-learning strategies that highlight the influence of the interaction between the criteria and the dimensions of sustainability regarding decision-making in an education environment. Furthermore, an extension of this method is the implementation of tools for decision-making among multi-stakeholders with different roles.

This paper provides a method that improves learning by using a simulated experience for decision-making, which focuses on the contribution of infrastructure to sustainability. The method considers the preference for sustainability given the initial conditions of awareness, interest and knowledge that a team of students has. In addition, the method has a rational and participatory approach that simulates multiple views from construction professionals regarding sustainability. This learning proposal can be replicated in every professional context that works with projects; of course, the case study would need to be adapted according to the field.

\section{Acknowledgments}

This research was made possible by the support of the Academic Head of the MSc in Planning and Management in Civil Engineering at the Universitat Politècnica de València. The authors are grateful to the students of the sixth and seventh editions of this program for taking part in this educational experiment, as well as to Joaquín Catalá, Juan José Clemente, Jaime Jiménez and Oscar Roselló for participating in the focus group. This research was also partially funded by the European Commission under the Erasmus Mundus Lindo 450 Program 
(grant EMA-2-2012-2658) and the Spanish Ministry of Economy and Competitiveness along with FEDER funding (project BIA2014-56574-R).

\section{References}

Alarcón, D.B., 2005. Modelo integrado de valor para estructuras sostenibles. Ph.D. Disertation. Universitat Politècnica de Catalunya, Barcelona (Spain).

Arroyo, P., Tommelein, I. D., Ballard, G., 2015. Comparing AHP and CBA as decision methods to resolve the choosing problem in detailed design. J. Constr. Eng. M. 141(1), 04014063. http://dx.doi.org/10.1061/(ASCE)CO.1943-7862.0000915.

Bilec, M.M., Ries, R.J., Matthews, H.S., 2009. Life-cycle assessment modeling of construction processes for buildings. Journal of Infrastructure Systems 16(3), 199-205. http://dx.doi.org/10.1061/(ASCE)IS.1943555X.0000022.

Boks, C., Diehl, J.C., 2006. Integration of sustainability in regular courses: experiences in industrial design engineering. J. of Clean. Prod. 14(9-11), 932-939. http://dx.doi.org/10.1016/j.jclepro.2005.11.038.

Bucciarelli, L.L., Einstein, H.H., Terenzini, P.T., Walser, A.D., 2000. ECSEL/MIT engineering education workshop '99: A report with recommendations. J. Eng. Educ. 89(2), 141-150. http://dx.doi.org/10.1002/j.2168-9830.2000.tb00508.x.

Byrne, E.P., Desha C.J., Fitzpatrick, J.J., Hargroves, K., 2013. Exploring sustainability themes in engineering accreditation and curricula. Int. J. of Sustain. in High. Educ. 14(4), 384-403. http://dx.doi.org/10.1108/IJSHE-01-2012-0003.

Dwyer, B., Byrne, E., 2010. Practical skills and techniques for the transition to a sustainable future, a case study for engineering education. In: Proc. of the 3rd Int. Symp. for Engineering Education, ISEE2010, University College Cork, 30 June-2 July, pp. 326-333.

Du, X., Su, L., Liu, J., 2013. Developing sustainability curricula using the PBL method in a Chinese context. J. of Clean. Prod. 61, 80-88. http://dx.doi.org/10.1016/j.jclepro.2013.01.012.

El-Adaway, I., Pierrakos, O., Truax D., 2015. Sustainable construction education using problem-based learning and service learning pedagogies. J. Prof. Iss. Eng. Ed. Pr. 141(1), 05014002. http://dx.doi.org/10.1061/(ASCE)EI.1943-5541.0000208.

FHWA, 2003. Economic analysis primer. Department of Transportation, FHWA, Office of Asset Management, Washington, D.C.

García-Segura, T., Yepes, V., Alcalá, J., 2014. Life-cycle greenhouse gas emissions of blended cement concrete including carbonation and durability. The International Journal of Life Cycle Assessment 19(1), 3-12. http://dx.doi.org/ 10.1007/s11367-013-0614-0.

George D., Mallery P., 2003. SPSS for Windows step by step: a simple guide and reference. 11.0 Update (4th ed.). Allyn \& Bacon, Boston, United States of America.

HEA, 2006. Sustainable development in higher education current practice and future development: progress report for senior managers in higher education. Higher Education Academy, Heslington, United Kingdom.

Huang, B., Yang, H., Mauerhofer, V., Gu, R., 2012. Sustainability assessment of low carbon technologies-case study of the building sector in China. J. of Clean. Prod. 32, 244-250. http://dx.doi.org/ 10.1016/j.jclepro.2012.03.031.

Jato-Espino, D., Castillo-López, E., Rodríguez-Hernández, J., Canteras-Jordana, J.C., 2014. A review of application of multi-criteria decision making methods in construction. Automat. in Construct. 45, 151162. http://dx.doi.org/ 10.1016/j.autcon.2014.05.013.

Jiménez, J., Pellicer, E., Yepes, V., 2011. Teaching and learning using a case study: application to a master degree in construction management. Procedia - Soc. Behav. and Sci. 15(1), 696-702. http://dx.doi.org/ 10.1016/j.sbspro.2011.03.167.

Kagawa, F., 2007. Dissonance in students' perceptions of sustainability and sustainable development: implications for curriculum change. Int. J. of Sustain. in High. Educ. 8(3), 317-338. http://dx.doi.org/10.1108/14676370710817174.

Kucukvar, M., Noori, M., Egilmez, G., Tatari O., 2014. Stochastic decision modeling for sustainable pavement designs. Int. J Life Cycle Ass. 19(6), 1185-1199. http://dx.doi.org/10.1007/s11367-014-0723-4. http://dx.doi.org/ 10.1007/s11367-014-0723-4.

Kumar, D., Katoch, S.S., 2014. Sustainability indicators for run of the river (RoR) hydropower projects in hydro rich regions of India. Renew. and Sustain. Energy Reviews 35, 101-108. http://dx.doi.org/ 10.1016/j.rser.2014.03.048. 
Labuschagne, C., Brent, A.C., van Erck, R.P., 2005. Assessing the sustainability performances of industries. J. of Clean. Prod. 13. 373-385. http://dx.doi.org/ 10.1016/j.jclepro.2003.10.007.

Lang, D., Scholz, R.W., Binder, C.R., Wiek, A., Staubli, B., 2007. Sustainability potential analysis (SPA) of landfills - a systemic approach: theoretical considerations a systemic. J. of Clean Prod. 15(17), 16281638. http://dx.doi.org/10.1016/j.jclepro.2006.08.004.

Lee, S., Kim, W., Kim, Y. M., Lee, H.Y., Oh, K.J., 2014. The prioritization and verification of IT emerging technologies using an analytic hierarchy process and cluster analysis. Technolog Forecast. and Soc. Change. 87, 292-304. http://dx.doi.org/ 10.1016/j.techfore.2013.12.029.

Lehmann, M., Christensen, P., Du, X.Y., Thrane, M., 2008. Problem-oriented and project based learning (POPBL) as an innovative learning strategy for sustainable development in engineering education. European Journal of Engineering Education $33 \quad$ (3), $281-293$. http://dx.doi.org/10.1080/03043790802088566.

Levitt, R.E., 2007. CEM research for the next 50 years: Maximizing economic, environmental, and societal value of the built environment. J. Constr. Eng. M. 133(9), 619-628. http://dx.doi.org/10.1061/(ASCE)0733-9364.

Lozano, R., 2010. Diffusion of sustainable development in universities' curricula: an empirical example from Cardiff University. J. of Clean. Prod. 18(7), 637-644. http://dx.doi.org/10.1016/j.jclepro.2009.07.005.

Lozano, R., Peattie, K., 2009. Developing a tool to audit curricula contributions to sustainable development. In: Sustainability at universities - opportunities, challenges and trends (vol. 31). Peter Lang Publishing Group, Frankfurt am Main, Germany.

Lozano, R., Young, W., 2013. Assessing sustainability in university curricula: exploring the influence of student numbers and course credits. J. of Clean. Prod. 49, 134-141. http://dx.doi.org/ 10.1016/j.jclepro.2012.07.032.

McCormick M., Lawyer K., Wiggins J., Swan C. W., Paterson K. G., Bielefeldt A. R., 2015. Sustainable engineering assessment using rubric-based analysis of challenge question responses. J. Prof. Iss. Eng. Ed. Pr. 141(2). C4014002. http://dx.doi.org/10.1061/(ASCE)EI.1943-5541.000021.

Medineckiene, M., Turskis, Z., Zavadskas, E.K., 2010. Sustainable construction taking into account the building impact on the environment. J. of Environ. Eng. and Landsc. Manage. 8(2), 118-127. http://dx.doi.org/ 10.3846/jeelm.2010.14.

Nelson, K. G., Shell, D. F., Husman, J., Fishman, E. J., Soh, L., 2015. Motivational and self-regulated learning profiles of students taking a foundational engineering course. J. Eng. Educ. 104(1), 74-100. http://dx.doi.org/10.1002/jee.20066.

Pappas, E., Nagel, R., Frazier, C., Hulleman, C., Benton, M., 2011. A contextual approach to researching and teaching sustainability. School of Engineering, James Madison University. Harrisonburg, VA.

Prince, M., 2004. Does active learning work? A review of the research. Journal of Engineering Education, 93(3), 223-231. http://dx.doi.org/ 10.1002/j.2168-9830.2004.tb00809.x.

Reyes, J.P., San-Jose, J.T., Cuadrado, J., Sancibrian, R., 2014. Health \& safety criteria for determining the sustainable value of construction projects. Safety Science 62, 221-232. http://dx.doi.org/10.1016/j.ssci.2013.08.023.

Saaty, T.L., 1987. The analytic hierarchy process - What it is and how it is used. Math. Model. 9(3 -5), 161176. http://dx.doi.org/ 10.1016/0270-0255(87)90473-8.

Saaty, T.L., Vargas, L.G., 2006. Decision making with the analytic network process: economic, political, social and technological applications with benefits, opportunities, costs and risks. Springer, New York, United States of America.

Segalas, J., Ferrer-Balas, D., Mulder, K.F., 2010. What do engineering students learn in sustainability courses? The effect of the pedagogical approach. J. of Clean. Prod. 18(3), 275-284. http://dx.doi.org/10.1016/j.jclepro.2009.09.012.

Sieffert, Y., Huygen, J.M., Daudon, D., 2014. Sustainable construction with repurposed materials in the context of a civil engineering architecture collaboration. J. of Clean. Prod. 67, 125-138. http://dx.doi.org/10.1016/j.jclepro.2013.12.018.

Sierra, L., Yepes, P., Pellicer, E., 2015. Social sustainability in the life cycle of Chilean public infrastructure. J. Constr. Eng. M., in press. http://dx.doi.org/10.1061/(ASCE)CO.1943-7862.0001099.

Sipos, Y., Battisti, B., Grimm, K., 2008. Achieving transformative sustainability learning: engaging heads, hands and heart. Int. J. of Sustain. in High. Educ. 9(1), 68-86. http://dx.doi.org/10.1108/14676370810842193.

Steiner, G., Posch, A., 2006. Higher education for sustainability by means of transdisciplinary case studies: an innovative approach for solving complex, real world problems. J. of Clean. Prod. 14, 877-890. http://dx.doi.org/ 10.1016/j.jclepro.2005.11.054.

Summers, M., Corney, G., Childs, A., 2004. Student teachers' conceptions of sustainable development: the starting points of geographers and scientists. Educ. Res. 46(2), $163-182$. http://dx.doi.org/10.1080/0013188042000222449. 
Torres-Machi, C., Carrion, A., Yepes, V., Pellicer, E., 2013. Employability of graduate student in construction management. J. of Prof. Issues in Eng. Educ. and Pract. 139(2), $163-170$. http://dx.doi.org/10.1061/(ASCE)EI.1943-5541.0000139.

Torres-Machí, C., Chamorro, A., Pellicer, E., Yepes, V., Videla, C., 2015. Sustainable pavement management: Integrating economic, technical, and environmental aspects in decision making. Transportation Research Record, in press.

Torres-Machí, C., Chamorro, A., Yepes, V., Pellicer, E., 2014. Models and actual practices in the economic and environmental evaluation for the sustainable management of pavements networks. Revista de Construcción. 13(2), 51-58.

Valdés-Vasquez, R., Klotz, L., 2011. Incorporating the social dimension of sustainability into civil engineering education. J. Prof. Issues Eng. Educ. Pract. 137(4), 189-197. http://dx.doi.org/10.1061/(ASCE)EI.19435541.0000066.

Valdés-Vasquez, R., Klotz, L., 2013. Social sustainability considerations during planning and design: framework of processes for construction projects. J. Constr. Eng. Manage. 139(1), 80-89. http://dx.doi.org/10.1061/(ASCE)CO.1943-7862.0000566.

Vila-Baños, R., Rubio-Hurtado, M., Berlanga Silvente, V., Torrado-Fonseca M., 2014. Cómo aplicar un análisis jerárquico en SPSS. Revista d’ Innovació i Recerca en Educació. 7(1), 113-127. http://dx.doi.org/10.1344/ reire2014.7.1716.

Ward, J.H., 1963. Hierarchical grouping to optimize an objective function. J. of the Am. Stat. Assoc. 58, 236244. http://dx.doi.org/10.1080/01621459.1963.10500845.

Watson, M.K., Lozano, R., Noyes, C., 2013. Assessing curricula contribution to sustainability more holistically: Experiences from the integration of curricula assessment and students' perceptions at the Georgia Institute of Technology. J. of Clean. Prod. 61, 106-116. http://dx.doi.org/10.1016/j.jclepro.2013.09.010.

Wemmenhove, R., de Groot, W.T., 2001. Principles for university curriculum greening. An empirical case study from Tanzania. Int. J. of Sustain. in High. Educ. 2(3), 267-283. http://dx.doi.org/10.1108/14676370110388354.

Whitmer, A., Ogden, L., Lawton, J., Sturner, P., Groffman, P.M., Schneider, L., Hart, D., Halpern, B., Schlesinger, W., Raciti, S., Bettez, N., Ortega, S., Rustad, L., Pickett, S.T.A., Killilea, M., 2010. The engaged university: providing a platform for research that transforms society. Front. in Ecol. and the Environ. 8(6), 314-321. http://dx.doi.org/10.1890/090241.

Wolters, W.T.M., Mareschal, B., 1995. Novel types of sensitivity analysis for additive MCDM method. Eur. J. of Oper. Res. 81, 281-290. http://dx.doi.org/ 10.1016/0377-2217(93)E0343-V.

World Commission on Environment and Development (WCED), 1987. Our common future. Oxford University Press, Oxford, United Kingdom.

Wright, T.S.A., Wilton, H., 2012. Facilities management directors' conceptualizations of sustainability in higher education. J. of Clean. Prod. 31, 118-125. http://dx.doi.org/10.1016/j.jclepro.2012.02.030.

Yepes, V., Pellicer, E., Ortega, A.J., 2012. Designing a benchmark indicator for managerial competences in construction at the graduate level. J. of Prof. Issues in Eng. Educ. and Pract. 138(1), 48-54. http://dx.doi.org/10.1061/(ASCE)EI.1943-5541.0000075. 